\title{
RURAL TERRITORIAL DEVELOPMENT POLICY IN ALAGOAS' ALTO SERTÃO, BRASIL
}

https://doi.org/10.4215/rm2019.e18007

Costa, J. E. Da ${ }^{*}$

(a) Doutor em Geografia (Universidade Estadual Paulista - Campus de Rio Claro).

ORCID: https://orcid.org/0000-0002-3777-5403. LATTES: http://lattes.cnpq.br/3081010498998044.

\author{
Article history: \\ Received 22 January, 2019 \\ Accepted 07 March, 2019 \\ Published 15 March, 2019
}

\section{(*) CORRESPONDING AUTHOR}

Address: Universidade Federal de Sergipe, Centro de Educação de Ciências Humanas, Departamento de Geografia. Av. Marechal Rondon, s/n Bloco Departamental II Jardim Rosa Elze 49100-000 - Sao Cristovao, SE - Brasil Telefone: (79) 21056742 - Ramal: 6742

E-mail: eloizio.npgeo@gmail.com

\section{ABSTRACT}

The policy of rural territorial development in Brazil goes through impasses and ruptures after thirteen years of execution, and it is pertinent to highlight the importance of analyzing case studies to understand the extent of its consolidation in Brazil. Initially, it is important to include the territory as a category that transcends geography in this area, involving related areas, in particular the question of the institutional capture of the category. The objective is to understand in this process the problematic of the so - called social management of rural territories as a governance mechanism in the line of rural development with territorial interface starting from the functioning of the Territorial Collegiate (CODETER), having as a case study the Territory of Alto Sertão Alagoano ( TASA). We deal with social management based on the documents produced between 2014 and 2017 of the collegiate plenaries of the territory on screen focusing on the issue of the correlation of forces of social actors represented in the collegiate, territorial guidelines and extraterritorial. The study is exploratory with a qualitative approach. The results demonstrated that the territorial approach is a phenomenon in consolidation and the arrangement operates as a very particular instrument, unlike other more conventional arrangements, involving integration issues in the rural world.

Keywords: Hail; Geostatistical tools; Civil Defense; Social Vulnerability.

\section{RESUMO / RESUMEN}

\section{POLÍTICA DE DESENVOLVIMENTO TERRITORIAL RURAL NO ALTO SERTÃO DE ALAGOAS, BRASIL}

A política de desenvolvimento territorial rural no Brasil passa por impasses e rupturas após treze anos de execução, sendo pertinente destacar a importância de analisar estudos de casos para entender a dimensão de sua consolidação no Brasil. Inicialmente, importante inserir o território como categoria que nesse aspecto transcende a Geografia, envolvendo áreas afins, em destaque da questão da captura institucional da categoria. O objetivo é entender nesse processo a problemática da chamada gestão social dos territórios rurais como mecanismo de governança na linha do desenvolvimento rural com interface territorial a partir do funcionamento do Colegiado Territorial (CODETER), tendo como estudo de caso o Território do Alto Sertão Alagoano (TASA). Abordamos a gestão social tendo como base documental as atas produzidas entre os anos de 2014 e 2017 das plenárias do colegiado do território em tela, pautando na temática da questão da correlação de forças de atores sociais representados no colegiado, das pautas territoriais e das extraterritoriais. O estudo é de caráter exploratório com abordagem qualitativa. Os resultados demonstraram que a abordagem territorial é um fenômeno em consolidação e o arranjo opera como instrumento bem particular, diferente de outros arranjos mais convencionais, envolvendo questões de integração do mundo rural.

Palavras-chave: Desenvolvimento territorial rural; colegiado territorial; Gestão social.

POLÍTICA DE DESARROLLO TERRITORIAL RURAL EN EL ALTO SERTÓN DE ALAGOAS, BRASIL

A política de desarrollo territorial rural en Brasil pasa por impasses y rupturas después de trece años de ejecución, siendo pertinente destacar la importancia de analizar estudios de casos para entender la dimensión de su consolidación en Brasil. En primer lugar, es importante insertar el territorio como categoría que en ese aspecto trasciende la Geografía, involucrando áreas afines, en destaque de la cuestión de la captura institucional de la categoría. El objetivo es entender en este proceso la problemática de la llamada gestión social de los territorios rurales como mecanismo de gobernanza en la línea del desarrollo rural con interfaz territorial a partir del funcionamiento del Colegiado Territorial (CODETER), teniendo como estudio de caso el Territorio del Alto Sertão Alagoano TASA). Se aborda la gestión social teniendo como base documental las actas producidas entre los años 2014 y 2017 de las plenarias del colegio del territorio en pantalla, pautando en la temática de la cuestión de la correlación de fuerzas de actores sociales representados en el colegio, de las pautas territoriales y de las extraterritoriales. El estudio es de carácter exploratorio con enfoque cualitativo. Los resultados demostraron que el enfoque territorial es un fenómeno en consolidación y el arreglo opera como instrumento muy particular, a diferencia de otros arreglos más convencionales, involucrando cuestiones de integración del mundo rural.

Palabras-clave: Desarrollo territorial rural; Colegio territorial; Gestión social. 


\section{INTRODUCTION}

In the arena of discussions on territorial issues in the rural sphere, it is important to articulate the relationship between public policy as a universal or focalist action of the State aimed at the most vulnerable populations, and its emergence as an institutional tool to understand the scope and the established limits of relationships of power. It is evident that this process is not configured by coercion or the use of the legitimate violence of power. This territorial bias acts as an instrument of "pacification" or even as a social pact of actors in a relevant socio-territorial process, insofar as the matters in question are the seemingly democratic forms of social participation in institutional arrangements, legitimized by power itself.

Thus, there are the Rural Territories and with an institutional extension, the Territories of Citizenship, which incorporate intersectoral attributions. The former were created in 2003 and the latter in 2008, their operational arrangement were the Territorial Colleges (CODETERs) with institutional attributes to construct rural agendas. Their collective basis was the question of the pragmatic social management of territorial development.

Hence the issue of deepening the dilemmas that the applied human and social sciences, as well as the responsible institutions, have called the "social management of the rural territories", in which they have approached concepts in the theme, mainly from a normative or academic institutional position (LEITE, 2009), and with some empirical support for state intervention or action. In this sense, the debate on territorial politics in Brazil is still open (or in consolidation). In addition, the analyses of empirical experiments need to be approached in the face of the diversity of this type of social management throughout Brazil, and more particularly in the territories of the Northeast, where more than half of the territories are located.

It is worth noting that this policy was practically excluded from the federal government's agenda in 2016, with the extinction of the Ministry of Agrarian Development (MDA) and its operational arm, the Secretariat of Territorial Development (SDT). Among the debris, some institutional arrangements that still "survive" can be highlighted both regarding mobilization and functioning. They are no longer financed by the Union's resources, as in the past, but are under the responsibility of those States interested in continuing them, like the state of Bahia. Some persist simply through "spontaneous" actions, thanks to the degree of organicity of the entities and institutions that worked in the territory, which evaluated the need to maintain them, due to territorial (or extraterritorial) agendas to be decided and executed in obedience to this policy's principles as a matter of territorial identity and social cohesion and that, for certain realities, reached a good level of organizational maturity.

This was the case with the institutional arrangement in the Territorial College of the Alto Sertão de Alagoas, which is analyzed in this article and is still functioning, despite operational difficulties. Nevertheless, this operation occurs with a certain regularity based on its organizational composition (Plenary, Directing Nucleus and Thematic Chambers) and the use of democratic instruments such as the discussions and collegial decisions of subjects set out in previously defined agendas. This experience needs to be analyzed in more depth and detail.

This study attempts to analyze the experiences regarding the social management of the territories as a case study, as well as the limits and scope of this policy that has been developed through the NEDET (Extension Nucleus in Territorial Development) a project in which the author participates in the state of Alagoas under the supervision and financing of the MDA in partnership with the National Council of Scientific and Technological Development (CNPq), based at the Graduate Program in Geography of the Federal University of Sergipe.

The article is divided into four parts besides this introduction. The second part analyzes what we call the institutional concept of territory, through a dialogue with renowned authors in the field of Geography, from the perspective of geographic thought, as well as the method and methodological procedures proposed and a more general characterization of the territory in question. The third part, approaches the issue from the experiences extracted from the case study, using documents produced at CODETER plenary sessions in the Alto Sertão Alagoano - the territorial acts - seeking to systematize the various topics discussed and forwarded to these collective monthly meetings. The last section presents the final considerations and the possibility of constructing themes for future studies in order to understand why the challenges still persist after thirteen years of territorial politics, despite the 
institutional dismantling of the policy. All of the above is anchored in the bibliographical references indicated at the end.

\section{TERRITORY AS AN INSTITUTIONAL CATEGORY: THEORETICAL AND METHODOLOGICAL BASES}

Undoubtedly, the category of territory integrates one of the main agendas, in both academic and institutional environments, given the ease of operationalizing these processes, such as the "territorialization" or "territoriality" of spatial phenomena. On the other hand, the malaise of this "territorial utilitarianism" is evident among several geographic scholars, to the extent that the category has been "captured" by related fields and principally by the State. To further complicate this issue, its content has been "contaminated" by erroneous concepts and definitions, outside of the theoretical and methodological order, disregarding a whole traditional trajectory of geographic thought, where the concept of territory incorporates a broad, deep theoretical framework through continuous debates, with constant changes synchronized with an increasingly complex reality. Especially from the perspective of the ills of the capitalist mode of production as regards the use (and abuse) of the territory and its processes of appropriation and expropriation.

The purpose of this text is not to address the multiplicity of studies on the concept (or definition) of territory, due to the analytical richness already produced and the existence of solid literature on the subject. However, there is a need for theoretical and methodological choices. Accordingly, one of the interesting studies that seeks precisely to rescue the concept of territory in a conception linked to these realities is SAQUET's contribution (2011, p 01), whose foundations systematize the multiscalarity of the social dimensions of territory and nature exterior to man. Its temporal cut corresponds to the 1970s and 1980s, when the influences of the historical and dialectical approaches were determinant, giving a new epistemological orientation to geographic thought, reversing the regionalist conceptions and of the exceptionality advocated by the new Geography.

However, one of the author's pearls is the importance of the northeastern geographer Manuel Correia de Andrade in the process of scientific formation of Brazilian geography. Influenced by foreign geographers, in particular of the French regionalism of Paul Vidal de La Blache, he introduced a "genuinely Brazilian" concept of classic territory that mixes elements linked to the regional question and the importance of economic development. Added to this is the issue of growth poles, applied institutionally in Brazil from the 1960s onwards, thanks to the influence of Francois Perroux's localization theory, particularly in the Northeast region, under the prism of industrial development on a regional scale.

On this question, Manuel Correia,'s attempt, using the methodological resources of classical geography, is precisely to articulate the concepts to be applied to the Brazilian reality, in view of the regional mosaic. The author salvages the trajectory of the intellectual from Pernambuco in his various works, particularly from his best-known book, Terra e o Homem no Nordeste ( Earth and Man in the Northeast),making it one of the greatest references in regional, economic and social studies.

Regarding Manoel Correia de Andrade's conception of territory, SAQUET (2011) analyzes that his approach goes beyond the formal interpretation of the territory from the Nation-State, stating:

Territory appears, once more, as the Nation-state, although qualified from broader power relations than those that extrapolate the State's action and involve social movements, especially the popular movements known as internal revolts that happened in Brazil. In general, he describes and makes a historical analysis of important aspects of some class conflicts that have occurred in this country. It can be characterized as a study of political geography, or rather, of the politics carried out in Brazil, especially in the post-Independence period, showing central processes in the formation of the Brazilian State. This reveals, along with other aspects of other works, significant permanencies in their thinking and approach, as well as in the conception of region and territory: they are formations substantiated from the action of the State and the regionally structured oligarchical groups. (p.11).

In the same vein, it is possible to insert the question of the concept of territory within the currents 
of geographic thought. There has been an inexorable metamorphosis in its conceptual trajectory, ranging from Ratzel's classical conception to its diversity within French thought, as well as regional geography, neopositivism, phenomenology and finally, critical geography.

Ratzel refines this concept from a political perspective, valuing the issue of the land and the role of the State. On addressing the thought of the German scholar, Valverde (2004, p. 119) states that:

According to Ratzel's seminal "anthropogeography", territory is the legal and moral expression of the state, the conjunction of land (Boden) and a people in which society is organized. This territoriality is associated to a specific identity, assuming that there are no internal subdivisions or contradictions in a given State, fixed in time and space, characteristics that could only be modified by the use of force (Raffestin, 1990; Souza, 1995). The movement of expansion of territories takes on an almost organic character, as a living being that develops and requires a larger area to occupy .

Therefore, these conceptual trajectories demonstrate that the process of understanding territory as a tool in the exercise of power over society is diverse and complex if approached from a historical perspective. More recent high-caliber authors in Geography, such as RAFFESTIN (1993), analyze the role of geographical science by focusing on the nature of power over the territory in its various elements, such as population, material resources of power and especially, the appropriation of other Geographical categories, such as space, region and place in the perspective of territorial power through territorial systems and / or territorialities.

On the other hand, the category of territory can be approached from the perspective of the conceptual appropriation carried out by professionals from the related areas of Geography, as occurs between researchers and policy makers, giving it a different meaning. This is the case, for example, of the institutional use of territory as a tool for planning, executing and evaluating the results of public programs and policies within the statehood of these actions, inducing even political vices, as in the lines of SABOURIN et al ( 2018, pp. 193), when they analyze the question of the low statehood of the programs aimed at family agriculture in Argentina due to these processes, which, undoubtedly, have a territorial nature:

Faced with low statehood, programs become overly dependent on those in public office during a specific mandate. Thus, public policies and programs become appropriated by the fellow-thinkers of a particular party or political group that is linked to a specific government mandate.

Returning to RAFFESTIN (1993), in this metamorphosis of space to territory, an important issue is the role of the social actor (or subject) as a representation who "territorializes" space and the use of power over it, including the use of a semantic structure of this representation. When addressing the importance of this structure, observed for example in Cartography, Raffestin emphasizes this territorialization in the problematic approach to the axiomatic applicability of the representation of the Earth, even if it is operationally limited. Its emergence coincides with the formation of National States, which gives meaning to territory:

Modern cartography appeared in the Renaissance. Therefore, it closely followed the birth of the modern state. Very quickly, it became an instrument of power and "Power." This cartography privileged a Euclidean "syntax" that certainly did not fail to contribute to modeling the behavior of power. This syntax is very effective, since it only mobilizes three fundamental elements: the surface or the plane, the line [...] and the point or moment in the plane. It is from the combination of these elements that the images or representations of space result. (RAFFESTIN, 1993, p.145).

He continues with regard to the exercise of state power since its formation under the capitalist mode of production:

The delimitation of a territory, the control of points, islands, cities, etc. and the layout of highways, roads, etc., do these not arise from a Euclidean axiom translated in terms of relations of power? Not only are we tempted to say so, we affirm it! The only thing that is not immediately possible to show is the system of axioms of these power relations. In order to arrive at these, it would be convenient to analyze, since the 
Renaissance, the great spatial policies of the States in relation to their territorial achievements. In their desire to reach the sea, to preserve access to highways, to set up cities, and to match a border with a line of crests or a river, States modulate their policies according to an axiom that is not clearly assumed but very present and very real. (RAFFESTIN, 1993, pp. 145/46).

In the trajectory of the geographical analysis of the multifaceted concept of territory, Milton Santos is preeminent. Considered the greatest theoretician of contemporary Brazilian Geography, his analytical interventions transcend Geography and serve as references in any study that has territory as its object or even in approaches that involve other categories, such as space and region.

SANTOS (2006) approaches territory with the questions of technique, space and science, as well as inequality as given, as a system of fixed and flows, which operate in spatial formation, or on their own terms, as a system of objects and systems of actions. Thus, from the territorial point of view, as a category, the author emphasizes the need for a "return to territory" in the contradictory perspective of globalization as a totality and fragmentation as a real place. This completes the need to understand the "use of territory" in a new dimension, involving science, technology and information, breaking the apparent characteristic rigidity of territory. This can be shaped according to the system of capital, as the author emphasizes:

Territories are forms, but the territory used is objects and actions, synonymous with human space, inhabited space. Even the analysis of fluidity put at the service of competitiveness, which today governs economic relations, passes through this. On the one hand, there is a virtual fluidity, offered by objects created to facilitate this fluidity, and which are, more and more, technical objects. However, objects offer nothing but a virtual fluidity, because the real comes from human actions, which are increasingly informed actions, normatized actions. (SANTOS, 1998, 16).

The central issue of SANTOS's analysis (1998) is precisely the applicability of the territory or its use, with an emphasis on the capitalist mode of production and with it the engendering of contradictions materialized in the territorial relations where power is exercised, not necessarily in line with power of the State, but more subtle forms of territorial power, represented by economic, mediatic, cultural power, etc. The territorial meaning of Milton Santos is open and shows the analytical complexity of a category dear to Geography, in which he approaches the theoretical wealth of understanding, within the framework of the capitalist mode of production, the subtleties of the use of territory hegemonically marked by relations of interests .

In this respect, the concept of territory cannot be exclusive to Geography or related areas, such as Political Science or Political Sociology, but rather by the ontological nature of this category, which has been revealed in the last decades as one of the strategies employed by the State apparatus for institutional actions, particularly from the perspective of territorial development, including state-level procedures, such as the existence of a state project, including the planning, execution, control and evaluation of results, with particular emphasis on public policies or the action of the State.

Hence our analytical insertion of the policy of rural territorial development, instituted since 2003, in the first mandate of President Luís Inácio Lula da Silva, which was maintained, despite great difficulties, until the middle of 2016. These were thirteen years of successful (and unsuccessful) attempts and constructive intentions to apply a public resource management model within the framework of social participation, through the decentralization of resources to be operationalized on a territorial dimension, through a social management model that was above the municipal model and below the level of the states, as well as the priority given to social control carried out by actors empowered in institutions.

Thus, to address what we are calling the institutional concept of the territory, the following statement extracted from an official document (MDA, 2005, page 5) is given below, in which the adopted concept inserts territory as:

A physical, geographically defined and generally continuous space, comprising the city and the countryside, characterized by multidimensional criteria - such as environment, economy, society, culture, politics and institutions - and a population with relatively distinct social groups, which relate 
internally and externally through specific processes, where one or more elements that indicate social, cultural and territorial identity and cohesion can be distinguished.

There are some interesting aspects in this definition. The first relates to the multidimensional aspect of territory, giving an idea of the operative multiplicity of the territory in the dimensions of a determined society, involving urban and rural spaces. A second aspect it that even with this multidimensionality, there are specific processes, depending on the social groups involved and thus the need to raise demands and interests that can be materialized in previously established institutions, such as CODETERs, where discussions and deliberations of actions can be developed in the line of rural territorial development. In this way, this process is materialized in a model of participatory democracy, going beyond an institution of a purely consultative nature. This strengthens rural social processes at the institutional level based on the territorial approach.

Finally, the question of identity, social, cultural and territorial cohesion is examined, demonstrating the multidimensionality of the definition. The first aspect is related to the difficulties in constituting identity in the territorial framework, to the extent that the territory itself has a deeply heterogeneous nature and is characterized in its essence by relations of power. Furthermore, the cohesions may configure the asymmetries of these elements, in social, cultural and territorial terms and, therefore, be marked by the distinction.

Fundamentally, the definition above has a connotation closer to region than territory, due to the content presented, giving it a guise of homogeneity ("physical, defined and continuous") in a heterogeneous and multifaceted territorial reality. It is within this approach that the analysis of what we call "aspects of territorial pragmatism" is approached from a concrete reality, inscribed in the institutional figure of rural territories or more appropriately the territories of citizenship.

In this way, from the point of view of territory, the issue of rural development takes place as one of the State's strategies of insertion in economically poorer territories of the country. The "use of territory" (Milton Santos' expression) gives meaning to this policy that now takes on a more pragmatic bias where some institutional principles are valued as a substrate for the issue of social management of a territory. Not as an individual product (in the conception of entrepreneurship), but as a collective product resulting in social and economic impacts within the territorial perspective, effectuated for the poorest in rural areas in the country.

Hence the importance of understanding the meaning and scope of "social management of territories", an experience developed in Brazil, which was a Latin American, rather than a genuinely Brazilian experience, as affirmed by PERAFÁN et al (2018, p. 01). This author sustains the importance of broadening the studies based on this approach, appropriating the narrative of representatives of social movements, managers and academics, giving them the contributions regarding the challenges and limitations of these actions with a territorial approach, and more importantly, of the singularities of these territories. Hence its complexity and heterogeneity.

Thus, the issue of territory is one of the main mechanisms where civil society and political-administrative institutions operate through pacts and consensuses, with discussion and deliberation, directing actions of social, economic and cultural intervention directed to the poorest in the countryside. The social management of rural territories (and citizenship) is the most effective operational mechanism in the rural development process.

PERICO (2009) addresses this issue as a guiding element in the implementation of public policies aimed at the rural world, articulating an integrated approach of what the author calls cycles in the social management of territories in the ambit of social responsibility of the economy and the need for territorial institutionality.

From this perspective, the processes that integrate the territories' social management cycles go through several phases to define their effectiveness as instrumentalization. In Brazil this operated in the rural territories and in the territories of the citizenship where the author affirms (PERICO, 2009):

In the social management cycle, territorial management processes imply and recognize the value, first of the organization, representation, and participation of communities, of organized society, for a dialogue between society and the State in development processes. The instrumentalization seen in the Territories of Identity and the Territories of Citizenship model implies consensual diagnostic processes, where there is a combination of 
objective diagnostic elements, technical elements, but where the important element is not the objective diagnosis as we have traditionally known it, but that the consensus on the elements of the problematization of the territory and the conditions that favor or limit development in the territories, become the central point of the discussion. (p.26).

Thus, according to the author, two more elements are centered in the relationship between the use of the territory and the social phenomenon of management as an instrument of action of the social actors, through social participation. The first is in the constitution of what the author calls "strategic territorial projects" involving a set of collective actions, transcending individual actions, which, even if aggregated, would not make sense as actions of a collective nature. That is, for him "The strategic territorial project has a clear condition of multidimensionality and integration. It is not full coverage, it is not exhaustive, but it has the ability to focus on all the different components of the territory." (PÉRICO, 2009, 27).

The second element is the inexorable political dimension of social management, which must be consolidated and is institutionally materialized through the arrangement of the Territorial Colleges. Furthermore, because we are really talking about public policy models, of models of this policy's action in our society, which are not products of a technical, academic model, rather a product, and this has to be strongly emphasized. (PÉRICO 2009, page 27).

It is from these foundations that we add the proposed territorial cut in the state of Alagoas. From the geographic point of view, according to SILVA (2018, pages 7 and 8 ) this empirical sample is

The territory of Alto Sertão Alagoano consists of eight municipalities, Água Branca, Canapi, Delmiro Gouveia, Inhapi, Olho D'Água do Casado, Pariconha and Piranhas, distributed in the Alagoana Microregion of São Francisco and in the Serrana Micro-region of the Sertão Alagoano. It has an area of 3,935.30 km², which corresponds to approximately $14.06 \%$ of the total area of the State, which is $27,933.1 \mathrm{~km}^{2}$ and has a population of 169,119 inhabitants.

He continues regarding its historical formation and the importance of the São Francisco river basin in this process and the territorial impacts:

The territory was formed from the occupation of farms of beef cattle and crops, besides the processing and industrialization of cotton. Of the eight municipalities that comprise it, three are bathed by the São Francisco River and, consequently, were impacted by the Xingó, Itaparica and Paulo Afonso hydroelectric plants, particularly Xingó, which caused radical changes in the life and identity of the sertanejo riverside dwellers, starting with the environment and eventually gaining cultural proportions.

Thus, the Alto Sertão Alagoano Territory (TASA) is the most distant from the state capital, Maceió; the territory's main city - Delmiro Gouveia - is $395 \mathrm{~km}$ from the capital of Alagoas. This establishes an important issue, which deserves to be explored in future studies on the territorial question: the territories farthest from the most dynamic urban centers are the ones with the greatest capillarity in terms of mobilization and, therefore, greater socio-territorial cohesion.

The present study is an exploratory one, and the approach is qualitative in nature within the territorial dimension instigated by a development policy, where two axes are fundamental: the question of the social management of these territories and the institutional actions of productive inclusion. Together, the two actions form the backbone of this policy, from the point of view of its execution. The first axis is addressed in this article, being of the greatest interest to the study.

This exploratory study is approached through the direct participation of the author in the main instance of the TASA collegiate - the plenary sessions - where agendas are constructed, permeated by discussions and deliberations of a territorial or extraterritorial character. Thus, this process came about through observation, as well as direct participation in the discussions, based on issues related to rural territorial development.

The approach is qualitative, based on data and information inscribed in the minutes of the plenary sessions, held monthly between 2014 and 2016. Thus, a proposed analytical classification was used to 
define the profile of the social actors who integrate the CODETER framework through the correlation of forces of the entities and institutions participating in the arrangement, as well as the approach in relation to territorial and extraterritorial agendas. The most common topics discussed and deliberated in these plenaries were highlighted and were qualitatively systematized in each of the subtopics of the article.

\section{DISCUSSIONS AND RESULTS}

It was possible to analyze some discussions and results that were observed during the period in which the author took part in the project linked to the MDA in the Territory of Alto Sertão in the state of Alagoas.

To this end, it is fundamental to add qualitative aspects of the work, taking as a parameter the schedules of the CODETER of TASA, within the methodology already detailed above. As has been pointed out, this is an exploratory approach, using qualitative data extracted from documents produced by the arrangement at its highest level: the territorial plenaries.

\section{1 - The correlation of the forces of entities and institutions of CODETER}

The TASA was one of the first to be formed in the "boom" of territorial politics in Brazil - in the second term of the Lula government - between the years 2005 and 2010. CODETER incorporates elements central to the materiality of a true territorial institution, such as the regularity of the plenary sessions, the permanent construction of territorial agenda, the setting of admissibility measures to the plenary sessions, the frequency of entities with the greatest capillarity in the territory and their greatest pearl: the effectiveness of the decisions taken, using instruments untested in territorial politics, such as monitoring and evaluation of deliberate actions.

It is in this context that we can infer that the correlation of forces between the entities and institutions participating in the arrangement is symmetrical. It is an evident perception, especially regarding the discussions, the composition of the agendas and the referrals made. As is very common in collegial arrangements, in practice proposals are not disputed when there are effective relations of interest. In the period of our involvement there was a kind of territorial cohesion in the deliberation of the proposals, and there was almost always consensus.

It is clear that such processes must be seen from the need to shape the 'opinion formers' or the hardcore of the collegiate body. This is a common phenomenon and often undermines the arrangement from within, destroying any pretension to strengthen the social management of the territories. This was the case in the CODETER of Alto Sertão, but with a specific characteristic: the legitimacy of the social actors who were the opinion formers, on the part of both civil society and the institutions representing political-administrative power, such as municipal representatives. This is observed in the terms of PERAFAN et al. (2018, emphasis added):

The territorial approach of a development policy is based on an integral proposal of planning public actions that is based on the recognition of the needs and potential of the regions and their capacities to respond to economic processes. Territories take on and face new dynamics, but their responsiveness depends on the availability of natural assets, the presence of trust and reciprocity, organizational capacity and decision-making, their cultural diversity, and their level of knowledge and economic condition. (p. 11).

Basically, there are five noteworthy entities and administrative institutions that permeate the discussions and decisions of the Alagoan CODAGER:

a - the representative of the Trade Union of the Federation of Workers of the State of Alagoas (FETAG), with its headquarters in the city of Inhapi / AL.

$\mathrm{b}$ - the representative of the City Hall of Delmiro Gouveia / AL.

$\mathrm{c}$ - the representative of COPPABCS - Small Farmers Cooperative of Community Seed Banks. Municipality of Delmiro Gouveia / AL.

$\mathrm{d}$ - the representative of the Municipal Secretariat of Agriculture of the City of Inhapi / AL. 


\section{e - the representative of the rural women of the municipality of Mata Grande / AL.}

In this understanding, these are the social actors of greatest capillarity and who categorically define the agendas and discussions of the plenary sessions. This is not necessarily a tactic or strategy to enforce their interests. On the contrary, when setting the agenda, this nucleus seeks precisely to open the debate and forward matters from initiatives by other social actors in CODETER that justify addition of more points to the plenary session and that have as a ballast "executable" issues in the territorial approach to development.

It is interesting to observe the process of defining the agenda, which are written in the month's interval between one plenary and another. As these plenary sessions are held every 30 days, the agendas are prepared, always varying from six to twelve points, or even more, for discussion and deliberation, in addition to any other business that deliberates cases of urgency on the day of the event .

These plenaries are always held in the city of Delmiro Gouveia, because of the ease of access for the collegiate's social actors, affecting, for example, the reasonable number of participants, usually around forty and even, not uncommonly, more than eighty representatives from entities and institutions.

The CODETER's plenary sessions in Alto Sertão de Alagoas are always held on the second Tuesday of each month, the result of an arrangement agreed with the State Police by the former MDA (currently extinct under the regime of President Bolsonario) which has lasted since 2005. This demonstrates the collegiate's ability to develop a pattern of social management of the territory based on the capacity of the actors involved and the existence of the phenomenon of social cohesion.

\section{2 - Of the territorial agendas}

In this experience, it is fundamental to understand the asymmetry observed in other territories of citizenship, especially in the articulation between the organs responsible for the policy at federal level and the concrete reality of these territories. The mistakes have been monumental, ranging from absolute ignorance of territorial realities, often nourished erroneously by territorial advisers (hired by NGOs and financed by the federal government), many of them political activists or "commissioned careerists" who did not master this policy, and the paltry results in the social management of the territories.

These agencies equipped the territories within a well-intentioned strategy, but it did not take effect in the face of iniquities and misconceptions, forming over time what we call "professionals of the territorial associations". Hence the political comings and goings, which then went through a "white" phase, before the period of the the present analysis. This was reflected in the fragility of the social management of these territories, always dependent on public resources for mobilization and operation.

However, our interest is not to deepen this issue, deserving of a specific study, even in the form of self-criticism of policy errors on various scales (national, regional and territorial), because this experience would not only be Brazilian but also Latin American, and the particularities must be valued to understand the scope and limits of this policy.

Interestingly, within this contradictory issue in social management and in CODETER, the process of "use of territory" as a development tool was relevant and showed the capacity of building actions based on territorial policy principles. The issue of social participation stands out and, in this respect, there was organicity in social mobilization, as well as in the functioning of the Collegiate.

In this area, the insertion of agendas and deliberations in the productive inclusion segment showed the maturity of the TASA's dialogue; productive inclusion as an instrument and action to implement public policies aimed at the rural world. This can be observed in some agendas, selected from the documents produced by CODETER:

2.1 - effectiveness of credit policies, discussed and addressed in various plenaries, including the presence of professionals from the area, usually from official financiers who presented the nature of the policy. It is important to note the possibility of giving greater capillarity to the policy, with proposals to increase credit among family farmers residing in the territory, such as the provisional registration extracted from the information gathered in the plenary among representatives of entities linked to organized civil society.

These referrals have had good results, surpassing, albeit relatively, the great problem in the segment of productive and targeted microcredit directed to family farmers: the

asymmetry

of 
information, which is characterized by the absence of institutional mechanisms that specifically guide the real application of resources for productive purposes. CODETER operates as one of these mechanisms to overcome this typical asymmetry of various public policies in Brazil, due to the capillarity of the representatives of civil society who are part of the arrangement.

2.2 - improvement of institutional purchases, this has become one of the permanent and fruitful discussions in CODETER's plenary sessions, with an emphasis on the Food Acquisition Program (PAA). It is the most well-known policy in the territory, despite having a fragile capillarity in the TASA, due to the low technical capacity of the political-administrative institutions involved in this policy, as well as operational obstacles. Nevertheless, among the representatives of entities that regularly integrate CODETER, there are good levels of information and knowledge regarding this policy that help to overcome one of the central issues in the development of family agriculture in the Northeast: commercialization without the intervention of the well-known, traditional middlemen who subordinate the less organized family farmers.

In a recent analysis, the issue of markets was the object of research in what was called the "social construction of markets" and that can be "conceived of as institutional structures built by the visible hands of individuals, organizations, companies and social movements" (NIEDERLE \& WEZ JUNIOR, 2018, p.11). These authors assert that so-called "food" markets are challenging and far more complex than those observed in institutional instances. That is, currently, family farmers must overcome institutional purchases and face a diversified market, but this can be done by consolidating institutional purchases, where family farmers know the mechanisms of the commercialization of agricultural products, destined to a broader market.

Returning to the case study, the problem of institutional markets is not new, and even if it can operate without the intervention of political-administrative institutions, the territory must still strengthen its entities, like cooperatives, which are present, but not yet organized to act in the institutional market. The irregularity of institutional purchasing practices in CODETER is interesting, indicating an interest in improvement, even though this policy has practically disappeared with the institutional break of 2016.

However, due to operational successes in the state of Alagoas, as observed in the territories of Mata and Agreste, from 2017 the state government, established government purchases in the format of the PAA as a government policy. This demonstrates the reach and capillarity of the results in the state, and certainly the territorial colleges are the most legitimate arena for debate. Hence the resilience of this agenda as a strategy for rural development within the territorial approach in the state of Alagoas.

2.3 - the capillarity of technical assistance and rural extension (ATER), and its inclusion in CODETER's agendas is one of the most difficult in the territory, since the issue of ATER remains a structural problem, especially for family agriculture in the state of Alagoas, considering that these state actions were practically decimated, in view of the scrapping of entities.

However, in the opinion of CODETER's members, this issue is a framework under construction for the territorial reality, including to overcome these structural problems. This process is explained by a methodology developed in the arrangement, where CODETER's discussions and deliberations with the institution responsible for ATER in the territory are articulated as a permanent agenda .

In this way, a partnership was established, albeit informally, between the arrangement and the Alagoan company of technical assistance (EMATER), characterized by constructive agendas, including: the presence of ATER in the family agriculture production units in the Canal do Sertão, its activities with women's groups in the municipality of Mata Grande, the holding of field days in the territory's municipalities, with the presence and participation of family farmers and several institutions, such as development agencies, municipal secretariats of agriculture, etc.

Even more relevant is the sharing of ATER's experiences in the monthly discussions, reinforced by the presence, on average, of 10 professionals working in eight of the territory's fourteen municipalities. Then again, in agendas where ATER is not part of the territorial discussions, the presence of these professionals is still of great strategic importance; in particular in the issue of family farming policies such as institutional purchasing and targeted and productive microcredit, or more common issues such as the discussions on creole seeds, training and marketing in short-chain markets.

As noted above, the issue of ATER in the state of Alagoas does not differ in relation to the 
technical assistance system in the country. This public policy faces a crisis that has dragged on for more than twenty years and even if private companies have entered into the execution of this policy, the results are still paltry. This process has also been observed in the territory, with the presence of two private technical assistance companies, with little reach and inconsistent results, due to the fragility of the infrastructure and technical staff available. It has transformed itself into a compensatory policy without any effectiveness in terms of productive inclusion, because of the lack of control or planning by its main protagonists.

In spite of these obstacles, the positive aspect from the perspective of territorial development and the role of social management of the territories under the collegiate ballast, makes the ATER agenda a relevant segment with regard to rural development in areas as poor and deprived as observed in the TASA.

2.4 - compliance with the territorial sustainable development plan (PTDRS) and the annual construction of the territory's actions - the existence of a territory is not a process in itself, but a multifaceted set of actions that lead to rural development along the lines of productive inclusion. Even if they are institutional products, the creation of rural territories and citizenship includes in its principles and objectives the issue of institutionality and social participation, and the need to build a work plan or PTWRS. Initially carried out under the tutelage of the territorial adviser, the plans should be revised after five years.

As it was established in the Alagoano CODAGER in 2010, the PTDRS was altered in 2015. This process was carried out by the territory's coordination, where several actions were evaluated, refashioned or added. In the 2017, the plans were changed again, formalizing the internal regiment, which had not yet been instituted. This is in accordance with the deliberations of the National Conference of Sustainable Rural Development held in 2013 in Brasilia, dissected by principles, objectives, actions, goals and the need to shape the PTDRSs respecting the particularities of the territories. In this respect, the CODETER of the Alagoan sertão fulfilled this in full.

In the same vein, a particularity of the territory in question was observed: the annual construction of the actions that will be implemented during the period. This innovative procedure has become one of the most relevant aspects of the territory. All the planning is done annually in two days in January, when a whole agenda is constructed to be executed during the year. Thus, the question of territorial agendas remains as a defining element, contributing towards a greater improvement of the actions, besides training whilst the process is developed among the social actors who participate in the arrangement.

Moving on to the extraterritorial agendas, also extracted from the documents produced by the Alagoano CODAGER.

\section{3 - Extraterritorial agendas}

With regard to the extraterritorial agendas, it is observed that this process reinforces policy in the TASA. Compared with other collective arrangements, such as the CMDRS (Municipal Council for Sustainable Rural Development), or more traditional councils, such as health and education, the Alagoan CODETER has its peculiarities, such as the focus on family agriculture and more broadly, on the role of rural development focused on the poorest rural regions, mainly in the Northeast region.

Thus, one of the CODETER's positive characteristics is the leadership capacity of its social actors, who, even without formal schooling, add their experience and deep knowledge of the rural world of the territory. Hence its regularity until the present (2019), overcoming the bottleneck of financial dependence for its operation, unlike the overwhelming majority of CODETERs in the Northeast, which depend on the availability of public resources for this purpose.

In this context, the accumulation of "extraterritorial agendas" shows the maturity of the arrangement insofar as it transcends CODETER's institutional nature. Thus, the need to discuss, deliberate and principally articulate actions that interest the entities and institutions that participate in the process, finds in the CODETER a way of broadening agendas through "relations of proximity" to produce an agenda of interest to social territorial actors.

That is, the arrangement's constitution is no longer an instance, via plenary, to discuss "territorial issues", going beyond this. Conveying demands where the issue of family farming is central, CODETER 
has become a strategic arena to overcome bottlenecks and problems linked to the development of this rural activity in this Alagoan territory.

This section only addresses three extraterritorial agendas referred to and deliberated in the CODETER, which we highlight as relevant agendas in the territory. They are as follows:

A - the regulation of water use from the Canal do Sertão - the largest infrastructure project in the territory in the last ten years that includes the transposed flow of the waters of the São Francisco river over the Alagoan territory, extending for more than $250 \mathrm{~km}$ to the territory of the Agreste. In the Alto Sertão stretch, which has been completed, CODETER has become the main protagonist in the discussions on the use of the canal's water, the central issue being the need to regulate use. The State Department of Infrastructure is responsible for the execution of the work, but all the processes are being passed to the collegiate, including the attribute of following up these actions, as part of the government's triple strategy in relation to the social purpose of water: human and animal consumption and irrigation.

The understanding is that these discussions, initiated in the first half of 2017, have given CODETER legitimacy considering the strong trend in the indiscriminate abuse of water, including unknown users or the misuse of purpose; even including the phenomena of illegal connections to the water supply. The perception of the "participation of civil society", in the narrative presented by the institutional representatives responsible for the construction of the canal is of fundamental importance. Therefore, because of the heterogeneity of the organizations, their articulation with institutions and their territorial experience (going beyond the municipal federative unit), CODETER plays this role in the development of the discussions regarding the canal in the stretch where it passes through the TASA.

Hence, over time, the CODETER of Alto Sertão Alagoano will play a crucial role in this issue, and even if it does not have the institutional backing of the Union or State, its regular operation - with monthly plenary sessions - will help strengthen its capillarity in relation to the themes of the rural world of the territory.

$\mathrm{B}$ - exchanges of experiences in the rural environment of the TASA with the resolution of issues is one of the most creative mechanisms of the CODETER, showing the strong capillarity observed through the diversity of the themes incorporated bearing on issues related to rural development, regardless of their particularities or differences, as long as there is convergence on the issue of family farming within a territorial perspective. At the municipal or state level this would be less viable.

In this manner, issues related to the organization of women, the problem of rural electrification or milk cooling tanks are common themes, focusing both on identifying and seeking solutions to problems at the institutional level. The collegiate is one of the forms of facilitating the resolution of these challenges. It should also be noted that failure to solve a particular problem does not mean its exclusion from future agendas. On the contrary, non-resolution is an insertion factor in the subsequent plenary agendas, until the issue is resolved. This mechanism is practically consolidated and is one of the collegiate's great achievements. Although operating with similar procedures to the sectoral councils (education, health, etc.), its particularity - to discuss and deliberate the rural world of family agriculture - is what allows the participation of civil society and institutions at their various levels to set out specific agendas based on the diversity of the social actors involved and their identification with rural issues.

$\mathrm{C}$ - holding dialogues with representative social actors from civil society or institutions is also one of CODETER's milestones in recent years. This agenda is a mechanism of the collegiate's institutionalization in expanding its range of action in the territory. The strategy is to bring social actors of importance in the territory and who have links with rural themes linked to family agriculture to the plenary. This process can be observed by the regular presence of representatives from municipalities that are not necessarily linked to the municipal secretariat of agriculture, but whose work forms an interface with themes articulated with the issue of infrastructure or the environment. One example is the problematic issue of the management of the slaughterhouse in the municipality of Delmiro Gouveia, which has a strong environmental impact, but which also includes dialogues related to agroecological practices, or the presentation of training proposals for family farmers or projects to be carried out by civil society entities such as ASA (Articulation of the Semi-arid), added to the most important extraterritorial agenda, which is the Dom Helder project, with a strong insertion in the territory, a project that operates practically throughout the semi-arid Northeast,

Thus, the manner of carrying out these processes, even if informal, shows the capacity of the 
territorial collegiate to articulate extraterritorial issues, focusing on the rural issues of the territory. We believe that these three analytical formats, with permanent agendas, contribute to the construction of a more effective process of the collegiate and product generation in the perspective of rural development focused on the territorial approach, particularly in the Northeast region.

\section{CONCLUSION}

Undoubtedly, there is a rich literature on the issue of rural territorial development in Brazil, as well as in Latin America, which support the elements that it aggregates, taking into account a crucial aspect: the need to carry out actions, mainly of an economic nature, but that are founded on the participation of civil society in the decision-making process; surpassing, albeit partially, traditional, top-bottom, vertical decision-making.

In this fashion, analyzing case studies is of fundamental importance as there is a diversity of territorial realities that must be added to this discussion agenda in order to improve the issue of rural territorial development in Brazil.

The issue presented in this article was aimed precisely to analyze a concrete case of social management of the territories from rural social processes based on the territorial collegiate of the Alto Sertão Alagoano, its operation and principally its results from the principle of social participation and bringing development to the main protagonists: family farmers.

In addition to the theoretical debate on the territory and its interface with geography and related areas, the key was to understand that the experiences, chiefly the good experiences, observed in specific territories, serve as ballast for the improvement of Brazilian rural territorial policy.

The case of the Alto Sertão Alagoano CODETER is an example of the scope and limits of an arrangement evidenced by the protagonism of the social actors who independently produce their agendas and generate products as mechanisms of rural development within the territorial approach. The separation into the three themes was a way of understanding the dynamics of the arrangement and the possibility of democratizing the decisions, aiming to improve the living conditions of the poorest population residing in rural areas of the upper Alagoan sertão. Added to this is the need to understand that rural social processes are in the process of being consolidated.

Thus, themes such as the "social management cycle of rural territories", analyzing the issue of territorial management alongside the policies of productive inclusion via territory, the analysis of the results of the infrastructure projects and the multidimensional nature of this policy, mainly in the Northeast, are included as emerging themes, insofar as the Brazilian experience has its particularities, and for the Northeast, where the social and economic impacts are more important due to the reality of rural poverty.

\section{BIBLIOGRAPHY}

ATAS das Plenárias Territoriais do CODETER do Alto Sertão Alagoano e FREQUENCIA dos participantes. 2015-2017. Arquivo particular. 2018.

PERAFÁN, Mireya E. Valencia \& et.alli. Gestão e Dinâmicas em Desenvolvimento Territorial. Curitiba: editora CRV. 2018.

PERICO, Rafael Echeverri. A Gestão Social dos Territórios: o desafio da multidimensionalidade in BACELAR, Tânia. Gestão Social dos Territórios. Brasília: IICA, 2009. Páginas 25/34.

BRASÍLIA. Ministério do Desenvolvimento Agrário - Marco Referencial para Apoio ao Desenvolvimento de Territórios Rurais, 2005.

NIEDERLE, Paulo \& WEZ JR. Valdemar João. As novas ordens alimentares. Porto Alegre: editora da Universidade Federal do Rio Grande do Sul, 2018.

LEITE, Sergio Pereira, KATO, K. \& ZIMMERMAN, S. Gestão Social: Reflexões \& Proposições. In: 
LEITE, Sergio Pereira (Org.). Gestão Social dos Territórios. Brasília: IICA, 2009.

RAFFESTIN, Claude. Por uma Geografia do Poder. São Paulo: editora Ática, 1993.

SABOURIN, Eric, BALESTRO, Moises \& SAYAGO, Doris. Circulação Regional e Origem das Políticas Públicas de DTR (Desenvolvimento Territorial Rural) na Argentina. In SABOURIN, Eric \& GRISA, Cátia (Orgs.). A Difusão de Políticas Brasileiras para a Agricultura Familiar na América Latina e Caribe. Porto Alegre: editora Escritos, 2018. p. 189/207.

SANTOS, Milton, SOUZA, Maria Adélia A. de \& SILVEIRA, Maria Laura. Globalização Fragmentação. São Paulo: editora HUCITEC, 1998.

SAQUET, Marcos Aurelio. Abordagens e concepções de território e territorialidade. Revista

Geográfica de América Central. San José/Costa Rica, Número Especial EGAL, 2011 - II Semestre 2011. p. 1-16.

SANTOS, Milton. A Natureza do Espaço: técnica e tempo, razão e emoção. São Paulo: editora da Universidade de São Paulo, 2006.

SILVA, Adriana Lisboa da. A Questão da Ater: Comentários iniciais na perspectiva das políticas públicas. Programa de Pós-Graduação em Geografia: Universidade Federal de Sergipe. Exame de Qualificação - Mestrado. 2018.

VALVERDE, Rodrigo Ramos Hospodar Felippe. Transformações no Conceito de Território: competição e mobilidade na cidade. São Paulo: GEOUSP - Espaço e Tempo. São Paulo, No 15, pp. $119-126.200$ 